\title{
Effect of cromolyn on adenosine-induced airway microvascular leakage in sensitized rats
}

\author{
J. Tamaoki, I. Yamawaki, M. Taira, Y. Nagano, J. Nakata, A. Nagai
}

\begin{abstract}
Effect of cromolyn on adenosine-induced airway microvascular leakage in sensitized rats. J. Tamaoki, I. Yamawaki, M. Taira, Y. Nagano, J. Nakata, A. Nagai. CERS Journals Ltd 1999.

ABSTRACT: Inhalation of adenosine causes bronchoconstriction in asthmatic subjects, but the effect of this purine nucleotide on airway vascular permeability is unknown.

In order to determine whether adenosine produces airway microvascular leakage and, if so, to examine the effect of cromolyn (sodium cromoglycate (SCG)) on this extravasation of Evans blue was measured in the airways of ovalbumin-sensitized Brown Norway rats.

Inhaled adenosine caused microvascular leakage in sensitized but not in nonsensitized rats, and the response was abolished by capsaicin pretreatment or the tachykinin neurokinin-1 receptor antagonist FK888. Adenosine-induced vascular leakage became apparent in nonsensitized rats when treated with phosphoramidon, and airway neutral endopeptidase activity was lower in sensitized than in nonsensitized animals. The extravasation induced by adenosine in sensitized rats was dose dependently inhibited by SCG aerosols. SCG likewise inhibited microvascular responses to substance $P$, but had no effect on those to platelet-activating factor.

These results suggest that: 1) adenosine induces airway microvascular leakage in sensitized rats through stimulation of neurokinin-1 receptors; 2) this effect is associated with a sensitization-induced decrease in neutral endopeptidase activity; and 3) sodium cromoglycate inhibits adenosine-induced extravasation, presumably via functional antagonism of tachykinins.

Eur Respir J 1999; 14: 1082-1087.
\end{abstract}

First Dept of Medicine, Tokyo Women's Medical University School of Medicine, Tokyo 162, Japan.

Correspondence: J. Tamaoki, First Dept of Medicine, Tokyo Women's Medical University School of Medicine, 8-1 KawadaCho, Shinjuku, Tokyo 162, Japan, Fax: 81353795457

Keywords: Antiallergic drug asthma

neutral endopeptidase

tachykinin

vascular permeability

Received: February 251999

Accepted after revision July 211999

This work was supported, in part, by Grant-in-Aid No. 06670632 from the Ministry of Education, Science and Culture, Japan.
Adenosine is a naturally occurring purine nucleotide formed by the cleavage of adenosine $5^{\prime}$-monophosphate by $5^{\prime}$-nucleotidase or by the catabolism of $S$-adenosylhomocysteine. Based on the findings that adenosine can be released from mast cells in both early- and late-phase asthmatic responses via antigen/immunoglobulin E (IgE) interaction after allergen bronchoprovocation [1] and that inhaled adenosine causes bronchoconstriction in asthmatics but not in normal subjects [2], this purine nucleotide is thought to play a role in the pathophysiology of asthma. Increased microvascular permeability and plasma protein extravasation in the airways might contribute to mucosal oedema, inflammatory cell infiltration and epithelial cell desquamation, which are characteristic features of asthma [3]. Previous studies have shown that adenosine induces plasma extravasation in rat skin [4] and hamster cheek pouch [5], but its effect on airway microvascular permeability is unknown.

Cromolyn (sodium cromoglycate (SCG)) is an antiallergic drug and has been widely used in the treatment of asthma $[6,7]$. Although SCG has long been recognized as a mast cell-stabilizing agent [8], its mechanism of action in asthma is still unclear. CROSSMAN et al. [9] showed that oedema formation in the human skin produced by substance P was reduced by SCG, suggesting that SCG may modify tachykinin actions. Therefore, the purposes of the present study were: 1) to determine whether adenosine produces airway vascular leakage; 2 ) to elucidate the possible involvement of tachykinins in the effect of adenosine; and 3) to determine whether SCG inhibits the effect of adenosine and, if so, what its mechanism of action is.

Neurogenic inflammation in the airway is modulated by the membrane-bound enzyme neutral endopeptidase (NEP, EC 3.4.24.11) [10]. Respiratory viral infections [11] and inhalation of occupational irritants [12] and cigarette smoke [13] exaggerate neurogenic inflammation by inhibiting endogenous NEP activity. Thus, the role of NEP in the vascular action of adenosine was also examined using phosphoramidon, a specific inhibitor of NEP [14], and by measuring the activity of NEP.

\section{Materials and methods}

Animals

Pathogen-free male Brown Norway rats (SLC Japan Co., Hamamatsu, Japan), weighing 250-300 g were used. The rats were kept in a temperature-controlled environment with standard laboratory food and water freely available for 3 days prior to the experiment. All experimental procedures were approved by the Committee on Animal Research of Tokyo Women's Medical University. 


\section{Study design}

The rats were sensitized by intraperitoneal injection of a $1 \mathrm{~mL}$ suspension of $1 \mathrm{mg}$ ovalbumin (Sigma Chemical Co., St Louis, MO, USA) and $100 \mathrm{mg}$ aluminium hydroxide (Wako Chemical Co., Osaka, Japan) in saline on three consecutive days. For nonsensitized controls, the rats were given $1 \mathrm{~mL}$ saline alone in a similar manner. Twentyone days after the initial injection, the animals were anaesthetized with intraperitoneal sodium pentobarbital (40 $\mathrm{mg} \cdot \mathrm{kg}^{-1}$ ), and the larynx and upper trachea exposed. The trachea was incised below the larynx, and a cannula inserted $4 \mathrm{~mm}$ into the trachea. The rats were then artificially ventilated at a frequency of 70 breaths $\cdot \mathrm{min}^{-1}$ and at a tidal volume of $10 \mathrm{~mL} \cdot \mathrm{kg}^{-1}$. A polyethylene catheter was inserted into the left carotid artery to monitor blood pressure using a pressure transducer (model TP-300T; Nihon Kohden, Tokyo, Japan).

In order to measure vascular extravasation, Evans blue ( $3 \%$ solution in $0.9 \% \mathrm{NaCl}$, Sigma) was used. Immediately after injection of the dye into the femoral vein $(30 \mathrm{mg}$. $\mathrm{kg}^{-1}$ ), aerosols of adenosine (Sigma) dissolved in saline were given for $2 \mathrm{~min}$ via the tracheal cannula using an ultrasonic nebulizer (aerosol delivery rate $0.2 \mathrm{~mL} \cdot \mathrm{min}^{-1}$, Pulmo-Sonic, model-25; De Vilbiss Co., Somerset, PA, USA). The chest was opened $5 \mathrm{~min}$ after the completion of adenosine inhalation, a cannula inserted into the ascending aorta through the left ventricle and the systemic circulation perfused with phosphate-buffered saline at a pressure of $13.3 \mathrm{kPa}(100 \mathrm{mmHg})$. After $2 \mathrm{~min}$ of perfusion, the right ventricle was opened and the pulmonary circulation perfused with additional phosphate-buffered saline for 1 min. The trachea and lungs were dissected out en bloc, the parenchyma gently scraped off and extraneous tissue removed. Then, the trachea, main bronchi and intrapulmonary airways were separated from each other. After blotting on absorbent paper, tissues were weighed and incubated in $3 \mathrm{~mL}$ of formamide (Kanto Chemical Co., Tokyo, Japan) for $18 \mathrm{~h}$ at $50^{\circ} \mathrm{C}$ to extract the extravasated Evans blue.

Firstly, regional differences in airway microvascular response to adenosine $\left(3,000 \mu \mathrm{g} \cdot \mathrm{kg}^{-1}\right)$ was studied in sensitized and nonsensitized rats. In evaluating the doseresponse relationship, the effects of increasing doses of adenosine $\left(100-3,000 \mu \mathrm{g} \cdot \mathrm{kg}^{-1}\right)$ on tracheal vascular permeability were examined in sensitized rats. In the control experiment, the rats received saline alone. Secondly, in order to detect the possible involvement of tachykinins in the adenosine action, the rats were pretreated subcutaneously with 25,50 and $100 \mathrm{mg} \cdot \mathrm{kg}^{-1}$ capsaicin (Sigma) dissolved in $10 \%$ Tween 80 and $10 \%$ ethanol in saline on the three consecutive days before sensitization [15]. A separate experiment showed that this procedure completely blocked vascular leakage induced by inhaled capsaicin $\left(10^{-5}\right.$ and $\left.10^{-4} \mathrm{M}\right)$, thus confirming capsaicin desensitization. Using these rats, the microvascular response to inhaled adenosine $\left(3,000 \mu \mathrm{g} \cdot \mathrm{kg}^{-1}\right)$ was studied. The effect of FK888, a selective neurokinin-1 $\left(\mathrm{NK}_{1}\right)$ receptor antagonist [16], on the adenosine action was also examined. In order to do this, FK888 $\left(10 \mathrm{mg} \cdot \mathrm{kg}^{-1}\right)$ was injected intravenously, and $15 \mathrm{~min}$ later aerosols of adenosine $\left(3,000 \mu \mathrm{g} \cdot \mathrm{kg}^{-1}\right)$ were given.

It is possible that airway vascular leakage induced by adenosine in sensitized rats could be related to alterations in endogenous NEP activity. To test this hypothesis, the microvascular responses of sensitized and nonsensitized rats pretreated with phosphoramidon were studied. The rats were given intravenous phosphoramidon $\left(2.5 \mathrm{mg} \cdot \mathrm{kg}^{-1}\right.$, Sigma), and $5 \mathrm{~min}$ later the effect of adenosine $(3,000$ $\left.\mu \mathrm{g} \cdot \mathrm{kg}^{-1}\right)$ on tracheal vascular leakage was determined. The dose of phosphoramidon was chosen based on a previous study [17], and preliminary experiments showed that phosphoramidon alone had no effect on microvascular permeability.

The effect of SCG (Fujisawa Pharmaceutical Co., Osaka, Japan) on the increase in vascular permeability caused by adenosine was then studied. Various doses of SCG (1$100 \mathrm{mg} \cdot \mathrm{kg}^{-1}$ ) were given by inhalation, and $5 \mathrm{~min}$ later intravenous Evans blue and inhaled adenosine (3,000 $\mu \mathrm{g} \cdot \mathrm{kg}^{-1}$ ) were given consecutively. Since the inhibitory effect of SCG on the adenosine-induced vascular leakage reached a plateau at a dose of $30 \mathrm{mg} \cdot \mathrm{kg}^{-1}$, it was determined whether this dose of SCG likewise inhibits the responses to other stimuli. Five min after SCG $(30 \mathrm{mg}$. $\mathrm{kg}^{-1}$ ) administration, Evans blue was injected and then various doses of substance P (3-300 $\mu \mathrm{g} \cdot \mathrm{kg}^{-1}$; Peninsula Laboratories, Inc., Belmont, CA, USA) or platelet-activating factor (PAF) L- $\alpha$-phosphatidylcholine- $\beta$-acetyl- $\gamma$ $O$-hexadecyl, $10-1,000 \mu \mathrm{g} \cdot \mathrm{kg}^{-1}$; Sigma) were given by inhalation. In preliminary experiments, $100 \mu \mathrm{g} \cdot \mathrm{kg}^{-1}$ substance $\mathrm{P}, 300 \mu \mathrm{g} \cdot \mathrm{kg}^{-1}$ PAF and $1,000 \mu \mathrm{g} \cdot \mathrm{kg}^{-1}$ adenosine were equipotent in increasing vascular permeability in the rat trachea. Substance $\mathrm{P}$ was dissolved in $0.9 \% \mathrm{NaCl}$, and PAF was prepared as a stock solution $\left(1 \mathrm{mg} \cdot \mathrm{mL}^{-1}\right)$ in $95 \%$ ethanol, stored at $-80^{\circ} \mathrm{C}$ and then diluted to the final concentration in $0.25 \%$ bovine serum albumin in $0.9 \%$ $\mathrm{NaCl}$. Separate studies showed that SCG at doses of up to $100 \mathrm{mg} \cdot \mathrm{kg}^{-1}$ per se did not change the baseline microvascular permeability of the rat trachea.

\section{Measurement of vascular permeability}

Extravasation of Evans blue-labelled macromolecules from the microcirculation in the airways was quantified by measuring the optical density of the formamide extracts at a wavelength of $620 \mathrm{~nm}$ using a spectrophotometer (Ultrospec Plus; Pharmacia LKB Biochrom, London, UK). The amount of Evans blue extravasated into the tissues, expressed in ng.mg wet weight ${ }^{-1}$, was interpolated from a standard curve of Evans blue concentrations $(0.1-5 \mu \mathrm{g}$. $\left.\mathrm{mL}^{-1}\right)$. A previous report demonstrated a close correlation between exudation of Evans blue, which binds to plasma albumin, and the leakage of radioiodinated serum albu$\min [18]$.

\section{Measurement of neutral endopeptidase activity}

The NEP activity was measured using a modification of the procedure of LLORENS et al. [19]. Briefly, the tracheae from sensitized and nonsensitized rats were minced and homogenized. The homogenates were incubated with a radiolabelled enkephalin analogue $\left({ }^{3} \mathrm{H}-\mathrm{Tyr}-\mathrm{d}-\mathrm{Ala}^{2}-\mathrm{leu}-\right.$ cine enkephalin, $20 \mathrm{nM}$, Amersham, Tokyo, Japan) in $125 \mathrm{mM} \mathrm{NaCl}$ containing $50 \mathrm{mM} \mathrm{N}$-2-hydroxyethylpiperazine- $N$-2-ethanesulphonic acid (HEPES) buffer $(\mathrm{pH}$ 7.4) for $40 \mathrm{~min}$ at $37^{\circ} \mathrm{C}$. Degraded ${ }^{3} \mathrm{H}$-Tyr-d-Ala ${ }^{2}$-leucine enkephalin was chromatographically separated from intact peptide and the radioactivity in each fraction was determined in a scintillation counter. The NEP activity 
was then determined by calculating the ratio of cleaved enkephalin to total ${ }^{3} \mathrm{H}$-Tyr-d-Ala ${ }^{2}$-leucine enkephalin, adjusted to the total protein content of the tissue, and enkephalin degradation expressed as fmol. $\mathrm{min}^{-1} \cdot \mathrm{mg}$ protein $^{-1}$.

\section{Statistical analysis}

All data were expressed as mean \pm SEM. The mean values of the spectrophotometric measurements of Evans blue extravasation were analysed by means of two-way analysis of variance. Comparisons between means in each condition were performed by means of Scheffe's F-test, n referring to the number of rats from which tracheae were taken and a p-value $<0.05$ was considered statistically significant.

\section{Results}

There was no significant change in mean blood pressure after inhalation of adenosine or SCG aerosols compared with saline in sensitized or nonsensitized Brown Norway rats. As demonstrated in figure 1, inhalation of adenosine $\left(3,000 \mu \mathrm{g} \cdot \mathrm{kg}^{-1}\right)$ caused microvascular leakage of Evans blue in the trachea and main bronchi but not the intrapulmonary airways in rats sensitized with ovalbumin, whereas it was without effect in nonsensitized animals. Therefore, only trachea were studied in the subsequent experiments. The adenosine-induced increase in tracheal microvascular permeability was dose-dependent (fig. 2), with significant vascular leakage observed at adenosine doses of $\geq 300 \mu \mathrm{g} \cdot \mathrm{kg}^{-1}$, and at $3,000 \mu \mathrm{g} \cdot \mathrm{kg}^{-1}$ adenosine the increase over control was $736 \pm 49 \%(\mathrm{p}<0.01, \mathrm{n}=9)$. Pretreatment of animals with capsaicin or FK888 abolished the vascular response to $3,000 \mu \mathrm{g} \cdot \mathrm{kg}^{-1}$ adenosine $(\mathrm{p}<0.01, \mathrm{n}=9$ for both).

In nonsensitized rats, pretreatment with phosphoramidon potentiated the adenosine $\left(3,000 \mu \mathrm{g} \cdot \mathrm{kg}^{-1}\right)$-induced microvascular permeability by $626 \pm 53 \%(\mathrm{p}<0.01, \mathrm{n}=10)$. In contrast, phosphoramidon did not further increase the vascular response to adenosine in sensitized animals (fig. 3 ). The activity of NEP in tracheal tissues was $327 \pm 80$ $\mathrm{fmol} \cdot \mathrm{min}^{-1} \cdot \mathrm{mg} \mathrm{protein}^{-1}$ in sensitized rats $(\mathrm{n}=9)$ and $981 \pm$ $92 \mathrm{fmol} \cdot \mathrm{min}^{-1} \cdot \mathrm{mg}$ protein ${ }^{-1}$ in nonsensitized animals $(\mathrm{n}=$ 10). There was a significant difference between these values $(\mathrm{p}<0.01)$.

As shown in figure 4, prior inhalation of SCG aerosols reduced the adenosine $\left(3,000 \mu \mathrm{g} \cdot \mathrm{kg}^{-1}\right)$-induced microvascular leakage in a dose-dependent manner. The maximal inhibition was $73 \pm 5 \%(\mathrm{p}<0.01, \mathrm{n}=10)$, and the dose of SCG required to produce a half-maximal effect was $15 \pm 3 \mathrm{mg} \cdot \mathrm{kg}^{-1}(\mathrm{n}=10)$. Inhalation of substance P or PAF produced a dose-dependent increase in microvascular leakage. Pretreatment with SCG aerosols $\left(30 \mathrm{mg} \cdot \mathrm{kg}^{-1}\right)$ inhibited the response of microvascular permeability to substance $P$ at $100 \mu \mathrm{g} \cdot \mathrm{kg}^{-1}$ and $300 \mu \mathrm{g} \cdot \mathrm{kg}^{-1}$ by $69 \pm 6 \%$ $(\mathrm{p}<0.01, \mathrm{n}=8)$ and $77 \pm 8 \%(\mathrm{p}<0.01, \mathrm{n}=8)$, respectively, but failed to affect PAF-induced vascular extravasation (fig. $5)$.
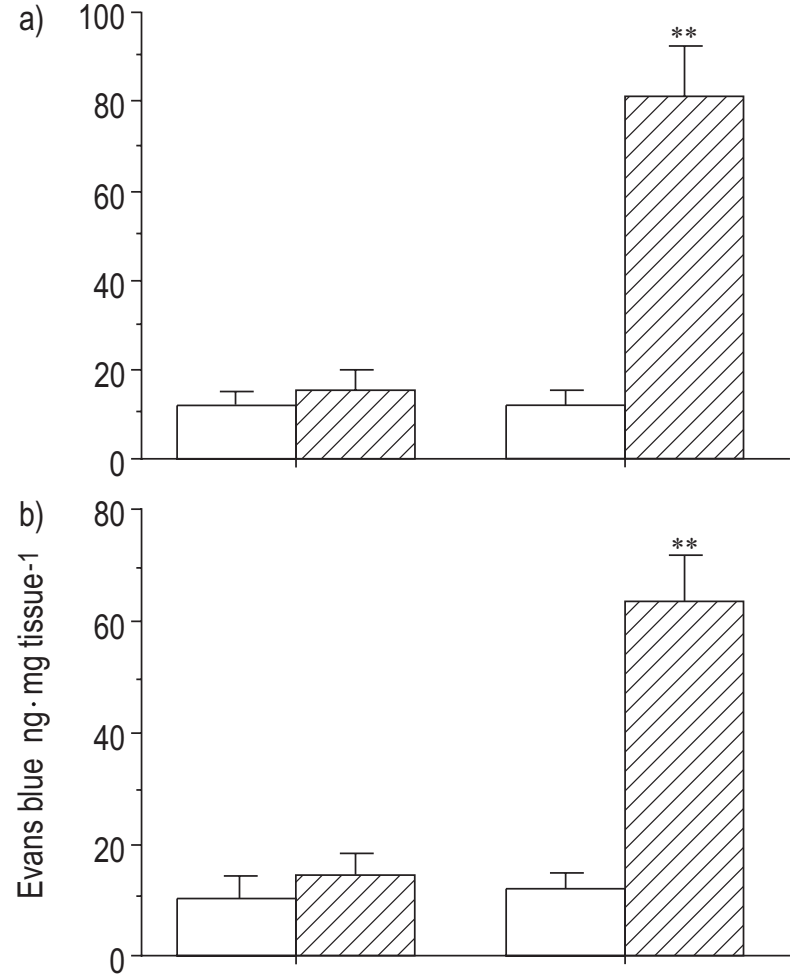

c)

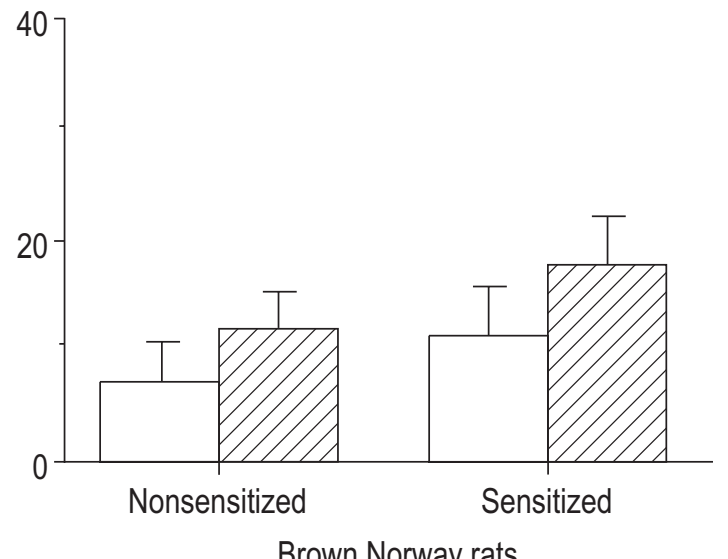

Fig. 1. - Effect of inhaled adenosine aerosols $\left(\mathbb{Z} ; 3,000 \mu \mathrm{g} \cdot \mathrm{kg}^{-1}\right)$ on airway microvascular permeability in nonsensitized and ovalbuminsensitized Brown Norway rats. $\square$ : saline alone. Vascular extravasation was evaluated by measuring the amount of Evans blue extravasated into: a) the trachea; b) the main bronchi; and c) intrapulmonary airways. Data are presented as mean \pm SEM $(\mathrm{n}=9)$. $* *$ : $\mathrm{p}<0.01$ versus corresponding control (saline).

\section{Discussion}

In the present study, plasma protein extravasation was assessed by measuring the tissue accumulation of Evans blue, which binds to plasma albumin. It is known that there is a close correlation between the exudation of Evans blue and that of radioiodinated serum albumin [18]. Based on ultrastructural, pathological and pharmacological studies, the site of airway microvascular leakage appears to be the postcapillary venules, whose endothelial cells contract in response to spasmogens, resulting in the formation of intercellular gaps [20]. Under this experimental condition, there were four major findings: firstly, inhalation of adenosine increases airway plasma protein extravasation 


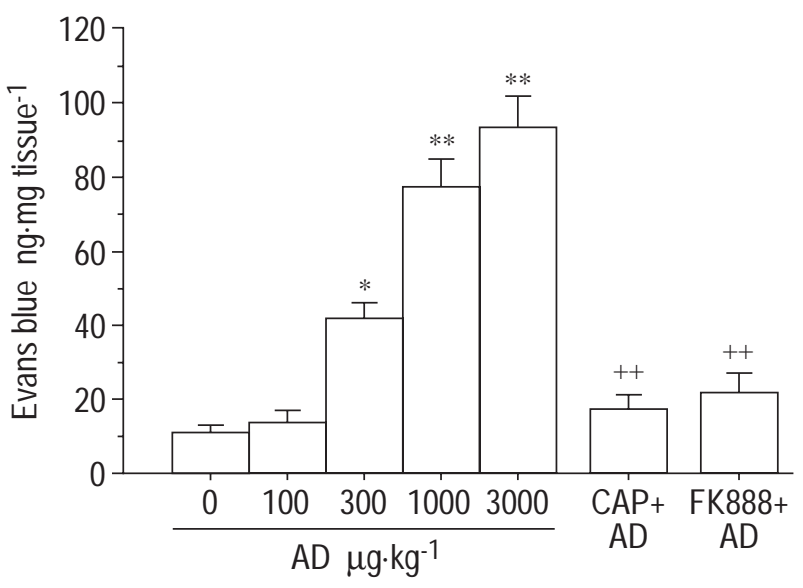

Fig. 2. - Effects of various doses of inhaled adenosine (AD) aerosols on tracheal microvascular permeability in sensitized rats. Some animals were pretreated with capsaicin (CAP) injection or FK888, and then given inhaled $\mathrm{AD}$ at $3,000 \mu \mathrm{g} \cdot \mathrm{kg}^{-1}$. Data are presented as mean \pm SEM $(\mathrm{n}=9) . *: \mathrm{p}<0.01, * *: \mathrm{p}<0.001$ versus control (saline); ${ }^{++}: \mathrm{p}<0.01$ versus $3,000 \mu \mathrm{g} \cdot \mathrm{kg}^{-1} \mathrm{AD}$ alone.

in sensitized Brown Norway rats; secondly, the response to adenosine is mediated by tachykinin stimulation of $\mathrm{NK}_{1}$ receptors; thirdly, sensitization decreases endogenous NEP activity, thereby potentiating the effect of adenosine; and fourthly, prior inhalation of SCG inhibits adenosine-induced vascular leakage, presumably through a functional antagonism of tachykinins.

Adenosine is a purine nucleotide released from mast cells through an IgE-dependent mechanism, and may play a role in the pathophysiology of allergic asthma. It has been shown that inhaled adenosine causes bronchoconstriction in patients with asthma but not in normal subjects [2], but the reason for this discrepancy remains unknown. It was found that inhalation of adenosine aerosols dose dependently produced tracheobronchial extravasation of Evans blue only in ovalbumin-sensitized rats. This is the first demonstration that adenosine is capable of increasing airway microvascular permeability. Subsequently, in order to elucidate the mechanism of adenosine action, the possible involvement of airway neurogenic inflammation was studied.

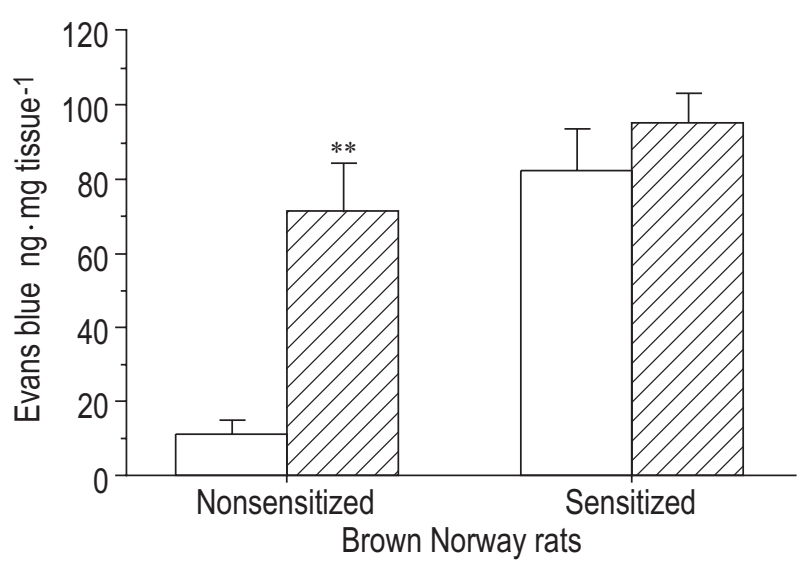

Fig. 3. - Effect of phosphoramide $(\mathscr{C})$ on tracheal vascular leakage induced by adenosine $(\square)$ aerosols in nonsensitized and sensitized rats. After intravenous injection of Phosphoramidon $\left(2.5 \mathrm{mg} \cdot \mathrm{kg}^{-1}\right)$, Evans blue and adenosine $\left(3,000 \mu \mathrm{g} \cdot \mathrm{kg}^{-1}\right)$ were consecutively given. Data are presented as mean \pm SEM $(\mathrm{n}=10) .{ }^{* *}: \mathrm{p}<0.01$ versus $\mathrm{AD}$ alone.

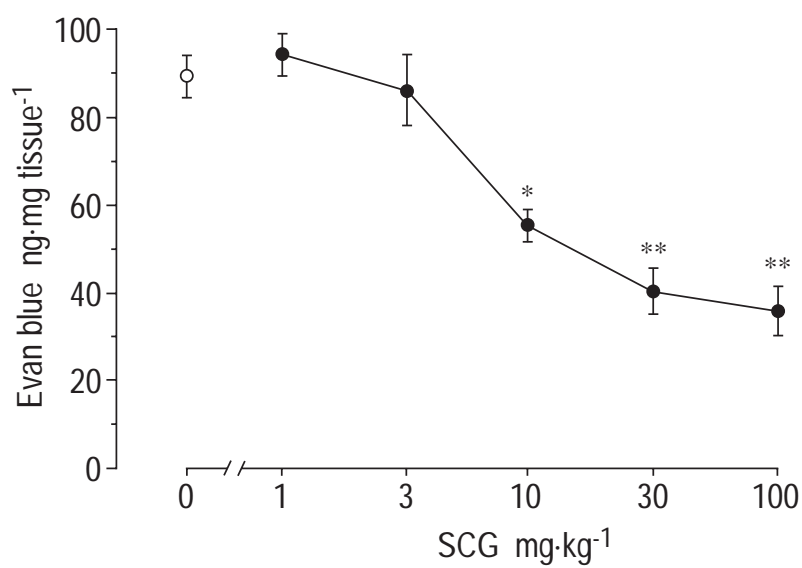

Fig. 4. - Dose-dependent effects of sodium cromoglycate (SCG) on tracheal vascular leakage induced by adenosine aerosols in sensitized rats. The rats received various doses of SCG aerosol by inhalation, and 5 min later Evans blue and adenosine $\left(3,000 \mu \mathrm{g} \cdot \mathrm{kg}^{-1}\right)$ were consecutively given. Data are presented as mean $\pm \operatorname{SEM}(\mathrm{n}=10)$. *: $\mathrm{p}<0.05 ; * *$ : $\mathrm{p}<0.01$ versus adenosine alone.

Stimulation of unmyelinated sensory nerves in the airway mucosa causes the release of tachykinins [21], which, in turn, produce plasma protein extravasation in rat airways [22]. To date, at least three subtypes of tachykinin receptor have been identified, denoted $\mathrm{NK}_{1}, \mathrm{NK}_{2}$ and $\mathrm{NK}_{3}$ [23], and plasma extravasation caused by sensory nerve stimulation in the rat trachea is mediated by $\mathrm{NK}_{1}$ receptor activation. Piedimonte et al. [24] showed that CP-99,994, an antagonist of $\mathrm{NK}_{1}$ receptors, inhibited plasma extravasation in the rat trachea produced by substance $\mathrm{P}$ and by stimulation of sensory nerves with capsaicin. In the present study, pretreatment of rats with capsaicin injection to deplete endogenous tachykinins or intravenous administration of the selective $\mathrm{NK}_{1}$ receptor antagonist FK888 [16] abolished adenosine-induced plasma extravasation. These findings suggest that adenosine may stimulate the release of tachykinins from sensory nerves, which consequently activate $\mathrm{NK}_{1}$ receptors on the endothelial cells of the postcapillary venules. In agreement with this notion, MEADE et al. [25] have recently shown that sensory nerve stimulation is involved in adenosine $A_{3}$ receptor-mediated bronchoconstriction in rats, but the involvement of this receptor subtype was not tested in the present experimental system.

In nonsensitized rats, adenosine produced vascular leakage in the trachea and main bronchi but had little effect in intrapulmonary airways. Similarly to this finding, previous studies have shown that plasma exudation induced by inflammatory mediators and antigen challenge is observed mainly in the large airways [26, 27]. This regional difference could be due to the difference in distribution of adenosine receptors and/or tachykinin-containing nerves between the central and peripheral airways. It is known that the membrane-bound NEPs are present in airway tissues [28], where the enzyme cleaves and inactivates tachykinins including substance $\mathrm{P}$ [29] and thus limits neurogenic inflammation [10]. Conversely, the decrease in endogenous NEP activity may result in the potentiation of neurogenic inflammation. In the present study, inhibition of NEP activity with phosphoramidon markedly potentiated adenosine-induced microvascular leakage in 

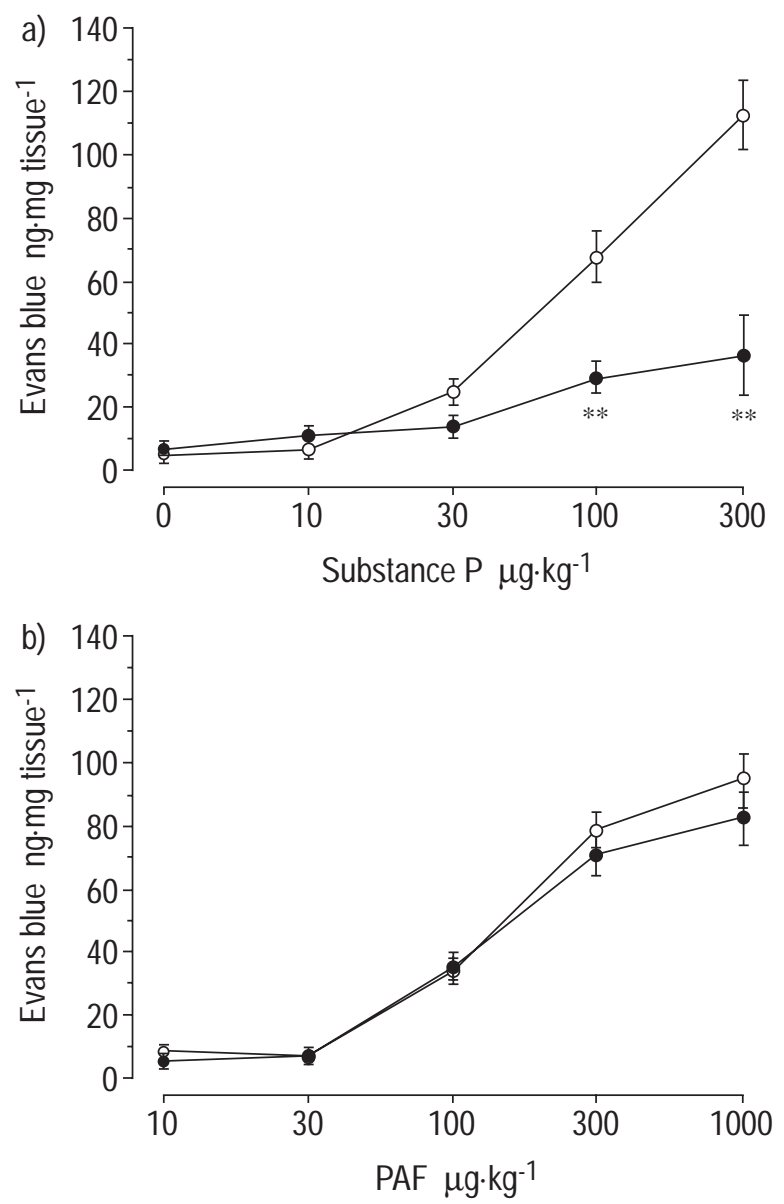

Fig. 5. - Effect of sodium cromoglycate (SCG) on tracheal vascular leakage induced by inhaled: a) substance $\mathrm{P}$; and b) platelet-activating factor (PAF) in sensitized rats. The rats received SCG aerosols (30 $\left.\mathrm{mg} \cdot \mathrm{kg}^{-1}\right)$ by inhalation, and $5 \mathrm{~min}$ later Evans blue and substance P (3$300 \mu \mathrm{g} \cdot \mathrm{kg}^{-1}$ ) or PAF $10-1,000 \mu \mathrm{g} \cdot \mathrm{kg}^{-1}$ ) were consecutively given $(\bullet)$. In the control experiments, the rats received substance P or PAF alone $(O)$. Data are presented as mean $\pm \operatorname{SEM}(\mathrm{n}=8) .{ }^{* *}: \mathrm{p}<0.01$ versus control.

nonsensitized rats, but was without effect in sensitized rats. Furthermore, it was found that NEP activity in tracheal tissues in sensitized animals was significantly less than that in nonsensitized ones. Therefore, the difference in microvascular responses to adenosine between sensitized and nonsensitized rats may be explained by the difference in endogenous NEP activity.

SCG was originally introduced as a mast cell-stabilizing drug and the first of a novel class of therapeutic agents for the treatment of allergic diseases [8]. However, its mast cell-stabilizing property is unlikely to explain the therapeutic efficacy of SCG in the treatment of asthma, because many compounds that are far more potent in stabilizing mast cells have failed to show therapeutic usefulness [30]. More recently, SCG has been shown to inhibit bronchoconstrictor responses evoked by irritants including bradykinin [31] and sulphur dioxide [32]. Because bradykinin and sulphur dioxide have no direct action on airway smooth muscle cells but stimulate autonomic nerve fibres, SCG may have the capacity to inhibit neurally-mediated airway responses. In addition, SCG inhibits substance P-induced oedema formation in the human skin [9] and bronchospasm in man [33]. These ob- servations raised the possibility that SCG might reduce the neurogenic inflammation mediated by capsaicin-sensitive sensory nerves in the airways; this effect is probably associated with the inhibition of tachykinin release and/or postjunctional action of SCG in antagonizing tachykinin receptors. In the present study, inhalation of substance $\mathrm{P}$ aerosols caused an increase in microvascular permeability, an effect that was inhibited by SCG to the same extent as observed in the experiment with adenosine aerosols. Thus, the site of SCG action may be postjunctional, and the authors speculate that this drug might antagonize tachykinin receptors. This hypothesis is supported by a previous autoradiographic study demonstrating that SCG inhibits the binding of substance $P$ to several tissues in vitro [9].

It is possible that SCG could have exerted the effects demonstrated in a manner independent of the stimulus, i.e. by acting directly on vascular endothelial cells and protecting against agonist-induced opening of intercellular gap junctions. However, this possibility seems unlikely, because, in contrast to its inhibitory effects on adenosine- and substance P-induced extravasation, SCG had no effect on the response to PAF, which is believed to directly open the gap junctions of endothelial cells and cause extravasation of macromolecules [34].

Airway inflammation, characterized by vascular leakage and infiltration of inflammatory cells, may be an important factor in the pathogenesis of asthma. Vascular leakage facilitates airway oedema, which may consequently produce epithelial cell damage, bronchospasm and airway obstruction [3]. The present results suggest that, when endogenous neutral endopeptidase activity is decreased after antigen sensitization, adenosine causes airway microvascular leakage through a tachykinin-dependent mechanism and that sodium cromoglycate inhibits this effect, presumably by acting at a postjunctional level to selectively inhibit tachykinin action on vascular endothelial cells. This novel anti-inflammatory effect could play a part in the therapeutic efficacy of sodium cromoglycate in inflammatory airway diseases.

\footnotetext{
Acknowledgements. The authors thank Y. Sugimura and M. Shino for their technical assistance. They also thank K. Takeyama for his important suggestions.
}

\section{References}

1. Marquardt DL, Gruber HE, Wasserman SI. Adenosine release from stimulated mast cells. Proc Natl Acad Sci USA 1984; 81: 6192-6196.

2. Ng WH, Polosa R, Church MK. Adenosine bronchoconstriction in asthma: investigations into its possible mechanism of action. Br J Clin Pharmacol 1990; 30: 89S-98S.

3. Chung KF, Rogers DF, Barnes PJ, Evans TW. The role of increased airway microvascular permeability and plasma exudation in asthma. Eur Respir J 1990; 3: 329-337.

4. Sugio K, Daly JW. Effect of forskolin on alterations of vascular permeability induced with bradykinin, prostaglandin $\mathrm{E}_{1}$, adenosine, histamine and carrageenin in rats. Life Sci 1983; 33: 65-73. 
5. Gawlowski DM, Duran WN. Dose-related effects of adenosine and bradykinin on microvascular permselectivity to macromolecules in the hamster cheek pouch. Circ Res 1986; 58: 348-355.

6. Benedictis FM, Tuteri G, Bertotto A, Bruni L, Vaccaro R. Comparison of the protective effects of cromolyn sodium and nedocromil sodium in the treatment of exerciseinduced asthma in children. J Allergy Clin Immunol 1994; 94: 684-688.

7. Edwards AM. Sodium cromoglycate (Intal@) as an antiinflammatory agent for the treatment of chronic asthma. Clin Exp Allergy 1994; 24: 612-623.

8. Cox JSG. Disodium cromoglycate: mode of action and its possible relevance to the clinical use of the drug. Br J Dis Chest 1971; 65: 189-204.

9. Crossman DC, Dashwood MR, Taylor GW, Wellings R, Fuller RW. Sodium cromoglycate: evidence of tachykinin antagonist activity in the human skin. $J$ Appl Physiol 1993; 75: 167-172.

10. Nadel A. Neutral endopeptidase modulation of neurogenic inflammation in airways. Eur Respir $J$ 1990; 3: 645S-651S.

11. Borson DB, Brokaw JJ, Sekizawa K, McDonald DM, Nadel A. Neutral endopeptidase and neurogenic inflammation in rats with respiratory infections. J Appl Physiol 1989; 66: 2653-2658.

12. Sheppard D, Thompson JE, Scypinski L, Dusser D, Nadel $\mathrm{JA}$, Borson DB. Toluene diisocyanate increases airway responsiveness to substance $\mathrm{P}$ and decreased airway neutral endopeptidase. J Clin Invest 1988; 81: 1111-1115.

13. Dusser DJ, Djokic TD, Borson DB, Nadel A. Cigarette smoke induces bronchoconstrictor hyperresponsiveness to substance $\mathrm{P}$ and inactivates airway neural endopeptidase in the guinea pig: possible role of free radicals. $J$ Clin Invest 1989; 84: 900-906.

14. Hudgin RL, Charleson SE, Zimmerman M, Mumford R, Wood PL. Enkephalinase: selective peptide inhibitors. Life Sci 1981; 29: 2593-2601.

15. Fujimura M, Amemiya M, Myou S, Mizuguchi M, Matsuda T. A guinea-pig model of ultrasonically nebulized distilled water-induced bronchoconstriction. Eur Respir J 1997; 10: 2237-2242.

16. Fujii T, Murai M, Morimoto $\mathrm{H}$, et al. Pharmacological profile of a high affinity dipeptide $\mathrm{NK}_{1}$ receptor antagonist, FK888. Br J Pharmacol 1992; 107: 785-789.

17. Umeno E, McDonald DM, Nadel JA. Hypertonic saline increases vascular permeability in the rat trachea by producing neurogenic inflammation. J Clin Invest 1990; 851: 1905-1908.

18. Rogers DF, Boschetto P, Barnes PJ. Plasma exudation: correlation between Evans blue dye and radiolabeled albumin in guinea pig airways in vivo. J Pharmacol Methods 1989; 21: 309-315.

19. Llorens CB, Malfroy B, Schwartz JC, et al. Enkephalin dipeptidyl carboxy-peptidase (enkephalinase) activity: selective radioassay, properties, and regional distribution in human brain. J Neurochem 1982; 39: 1081-1089.
20. Persson CGA. Role of plasma exudation in asthmatic airways. Lancet 1986; 2: 1126-1128.

21. Lundberg JM, Franco-Cereceda A, Hua X, Hökfelt T, Fischer JA. Co-existence of substance P and calcitonin gene-related peptide-like immunoreactivities in sensory nerves in relation to cardiovascular and bronchoconstrictor effects of capsaicin. Eur J Pharmacol 1985; 108: 315-319.

22. Umeno E, Nadel JA, Huang H-T, MeDonald DM. Inhibition of neutral endopeptidase potentiates neurogenic inflammation in the rat trachea. $J$ Appl Physiol 1989; 66: 2647-2652.

23. Regoli D, Drapeau G, Dion S, Couture R. New selective agonists for neurokinin receptors: pharmacological tools for receptor characterization. Trends Pharmacol Sci 1988; 9: 290-295.

24. Piedimonte G, Bertrand C, Geppetti P, Snider RM, Desai $\mathrm{MC}$, Nadel JA. A new $\mathrm{NK}_{1}$ receptor antagonist (CP$99,994)$ prevents the increase in tracheal vascular permeability produced by hypertonic saline. J Pharmacol Exp Ther 1993; 266: 270-273.

25. Meade CJ, Mierau J, Leon I, Ensinger HA. In vivo role of the adenosine $\mathrm{A}_{3}$ receptor: $\mathrm{N}^{6}-2$-(4-aminophenyl)ethyladenosine induces bronchospasm in BDE rats by a neurally mediated mechanism involving cells resembling mast cells. J Pharmacol Exp Ther 1996; 279: 1148-1156.

26. Erjefält I, Persson CGA. Inflammatory passage of plasma macromolecules into airway and lumen. Pulm Pharmacol 1989; 2: 93-102.

27. Sertl K, Kowalski ML, Slater J, Kaliner MA. Passive sensitization and allergen challenge increase vascular permeability in rat airways. Am Rev Respir Dis 1988; 138: 1295-1299.

28. Johnson AR, Ashton J, Schulz WW, Erdos EG. Neutral metalloendopeptidase in human lung tissue and cultured cells. Am Rev Respir Dis 1985; 132: 564-568.

29. Matsas R, Kenny AJ, Turner AJ. The metabolism of neuropeptides: the hydrolysis of peptides, including enkephalins, tachykinins and their analogues, by endopeptidase-24.11. Biochem J 1984; 223: 433-440.

30. Stokes TC, Morley J. Prospects for an oral Intal. Br J Dis Chest 1981; 75: 1-14.

31. Fuller RW, Dixon CMS, Cuss FMC, Barnes PJ. Bradykinin-induced bronchoconstriction in humans: mode of action. Am Rev Respir Dis 1987; 135: 176-180.

32. Myers DJ, Bigby BG, Boushey HA. The inhibition of sulfur dioxide-induced bronchoconstriction in asthmatic subjects by cromolyn is dose dependent. Am Rev Respir Dis 1986; 133: 1150-1153.

33. Crimi N, Palermo F, Oliveri R, et al. Bronchospasm induced by inhalation of substance P: effect of sodium cromoglyeate. Respiration 1988; 54: 95S-99S.

34. Kirsch CM, Brokaw JJ, Prow DM, White GW. Mechanism of platelet activating factor-induced vascular leakage in the rat trachea. Exp Lung Res 1992; 18: 447459 . 